\title{
Influence of Human Resource Accounting Practices on Managerial Decision-Making
}

\author{
James 0 Abiola \\ Department of Accounting, Faculty \\ Management Sciences, Lagos State University. \\ Rilwan Ayinde Adisa \\ Department of Accounting, Faculty \\ Management Sciences, Lagos State University.
}

\begin{abstract}
The study examined the influence of Human Resource Accounting (HRA) practices on managerial decision-making. Data for the study were gathered via a structured questionnaire on a 5-Points Likert Scale administered on personnel of Accounting, and Audit/Internal Control departments which were considered to be the relevant departments for this study in 16 quoted firms in the Nigerian financial services sector. The questionnaires distributed were returned and analyzed using a simple regression analysis model. The study found that HRA has a significant impact on managerial decision-making of organizations. It was therefore recommended that organizations should be more proactive in the use of HRA to enhance decision-making. Necessary and relevant standards should also be provided on the need for recognizing human resource cost in organizations' statement of financial position in order to enhance adequate decision-making in business organizations premised on fair financial reporting.
\end{abstract}

Keywords: human resources accounting, management, decision-making, managerial planning

\section{INTRODUCTION}

The trend of operation and the rate of competition among businesses in the global world calls for timely, effective and efficient decision to ensure success in terms of outstanding performance and eventual survival in a highly competitive economic environment. The going concern yearned for by various business organizations might not be sustainable if timely and continuous decisions are not taken on the available resources of the organization especially human assets. The importance of human assets as a key factor to the success and survival of the organization among other resources such as money, machine, minute (time) cannot be over-emphasized. In the words of Bassey and Arzizeh (2012), human resources have been identified as one of the main sources of competitive advantage by many organizations in today's economy. Fariborz and Rajashekar (2011) asserts that skillful and specialized human resources are of vital importance for an organization just like its physical properties and investments, Arkan (2016) posited that human is the most 
important resource of an organization because it controls and directs the other resources. In other words, people within an organization directly influence the success or failure of that organization. However, business enterprises often proclaim that their labour force is their most important asset, while at the same time they fail to recognize it in managerial planning, decision-making and in published annual reports (Fariborz \& Rajashekar, 2011). In the 21stcentury, the significance of human intellectual capital is most necessary than other capital in an organization (Anita \& Nader, 2014). However, to ensure complete business information goal congruence, Enyi and Adebawojo (2014) stated that there is need to value human asset and reflect this value in the financial statement like other intangible assets; hence, the need for Human Resource Accounting (HRA) data disclosure.

Micah, Ofurum and Ihendinihu (2012) concludes that human resource accounting information of an organization is a very important factor for decision makers in an era of knowledge based economy. According to Enyi and Adebawojo (2014), since human beings control and drive every other resources of organization, the quality of decisions made by them may either directly or indirectly reflects on the organization performance.

The recent consideration and recognition of human resources of an organization as being key factor to organizational survivalgave rise to researches locally and internationally. According to American Accounting Association (1973: 169), the purpose of HRA is to improve the quality of financial decisions made both internally and externally concerning an organization. Micah, Ofurum and Ihendinihu (2012) asserted that there is growing evidence of the interest and demand among stakeholders for information from firm in relation to human capital. Human Resources are important assets of an organization. However, there is no legal regulation for accounting human resources in any of the organization's annual report (Cherian \& Farouq, 2013). To make it more succinctly clear, Badmus and Abata (2010) posited that in spite of the available regulations such as Companies and Allied Matters Act 1990 (CAMA 1990 as amended), Banks and other Financial Institutions Act 1991 (BOFIA), Financial Bulletins issued by the Central Bank of Nigeria (CBN) and others, guiding the conduct of accounting and related services in Nigeria, none of these foundational principles and practices considered human capital reporting when drafted.

In the light of the foregoing, this paper examines the influence of Human Resource Accounting on Managerial decisions of firms in Nigeria.

The paper is divided into five sections. Section one dealt with introduction. The second section was on the review of literature. Methodology and data analysis were treated in the third and fourth sections respectively. The fifth section is on conclusion and recommendations.

\section{OBJECTIVES OF THE STUDY}

The main objective of this paper is to empirically examine the influence of Human Resource Accounting (HRA) on managerial decision-making. On the other hand, the specific objective of the study is to examine the significance of HRA in the context of management planning on human resources.

\section{Research Hypothesis}

The guiding research hypothesis for this study is: 
Abiola, J. O., \& Adisa, R. A. (2020) COVID-19: Influence of Human Resource Accounting Practices on Managerial Decision-Making. Archives of Business Research, 8(5). 8-18.

$\mathrm{H}_{0}$ : HRA practice has no significant effect on managerial decision-making.

\section{LITERATURE REVIEW}

This section reviews prior studies in the area of Human Resource Accounting and managerial decision-making.

\section{Empirical Review}

American Accounting Association (1973: 169) defines Human Resource Accounting as the process of identifying and measuring data about human resources and communicating this information to interested parties. In the words of WoddruffJr., Vice President, RG. Barry Corporation, the company which undertook pioneering work (1960s) in developing Human Resource Accounting, human resource accounting is an attempt to identify and report investment made in resources of the organisation that are not presently accounted for under conventional accounting practice. Woodruff further considers it to be an information system that tells management what changes over time are occurring to the human resources of the business. According to Bhumika (2016), Human Resources Accounting is an accounting of identifying, measuring, classifying, summarizing and reporting the data about human resources to the investors for effective decision-making regarding the human resources of an organization. American Accounting Association (1973: 169) states that the purpose of HRA is to improve the quality of financial decisions made both internally and externally concerning an organization. The main objectives of HRA isto: improve management by analyzing investment in HR; consider people as organization's asset; measure the cost and value of people to organizations; attract and retained qualified staff/workforce; profile the organization in financial term; and investigate the cognitive and behavioural impact of HR information.

Enyi and Adebawojo (2014) investigated the probable effect of Human Resource Accounting on the decision making process and business valuation method. The study which was carried out on 16 publicly quoted Nigerian banks adopted Ex-post facto research design. Data gathered via questionnaire were analyzed using statistical regression analysis. The result presented a significant effect of human asset accounting on management decision.

Fariborz and Rajashekar (2011) investigated whether investment decisions are affected by human resource accounting information disclosed in the financial statements or not. The study also examined the evaluation method of human resource which is the most appropriate method consistent with Iranian companies in terms of qualitative characteristics of accounting information. The findings revealed that HRA information disclosure in financial statements is relevant and it equally affects the optimal investment decisions. It was also discovered that the most effective and appropriate evaluating method of human resource consistent with current status of Iranian companies and institutions is the original cost method (Historical cost).

Anita and Nader (2014) explored the important role of human resource accounting on managers' decision-makingin organizations. It also studied how managers can put the human resource value in balance sheet (position statement)by different models. Primary data were collected through questionnaire distributed among some selected companies to examine the contribution of managers of organization and the extent at which human resource accounting affected managers' decision-makings. 
Isaac, Mayor and James (2017) studied the influence of human capital accounting information on the market value of listed oil and gas companies in the Nigerian Stock Exchange (NSE). Data sourced from the companies' annual reports and accounts from 2005 to 2015 and the Fact Books published by NSE were analyzed with Econometric regression. The findings revealed that human capital cost has a positive and a substantial relevance to share price. Consequently, the capitalization of corporate investment on its human resource has the propensity of increasing the market value of oil and gas companies and also capable of creating a favorable image for quoted oil and gas companies in Nigeria.

Islam, Kamruzzaman and Redwanuzzaman (2013) studied on the recognition and disclosure of accounting methods and techniques in relation to human resource accounting found that HRA develops effective managerial decision making.

Ezejiofor, John-Akamelu and Iyidiobi (2017) examined the adoption of Human Resource Accounting - with specific concentration on increase in staff salary, increment in staff and staff retirement benefits - on the Profitability of selected ten (10) commercial banks in Nigeria. They adopted exploratory research design and time series data. The data gathered were analyzed using t-test statistics. The study found that increase in staff salary has positive effect on organizational profitability; also that the level of increment in the number of staff has influence on organizational profitability. The study also revealed that staff retirement benefits have positive effect on organizational profitability.

Isaac, Mayor and James (2017) studied the influence of human capital accounting information on the market value of listed oil and gas companies in the Nigerian Stock Exchange (NSE). Data were sourced from the companies' annual reports and accounts from 2005 to 2015. The findings revealed that human capital cost has a positive and a substantial relevance to share price. Consequently, the capitalization of corporate investment on its human resource has the propensity of increasing the market value of oil and gas companies and also capable of creating a favorable image for quoted oil and gas companies in Nigeria.

Enofe, Mgbame, Otunya and Ovie (2013) examined the relationship between financial performance and human resources accounting disclosuresin fifty (50) quoted firms in Nigeria and the differences in human resources accounting disclosures reporting level between financial sector and non-financial sector companies, on the other hand. Data collected were analyzed using Multiple Regression. The findings revealed a positive relationship between the financial performance of a company and its level of Human Resource Accounting Disclosure. It was also found that financial institutions were disclosing human resources accounting information more than non-financial companies; and the company's profitability positively influences companies to report the human resources accounting information in their annual report.

Ogenyi and Oladele (2015) investigated the effect of the main challenges to accounting for Human Resources in Nigeria. The data collected through survey instrument given to selected accounting professionals and experts were analyzed using Binomial Logistic Regression. The principal factors identified as challenges were categorized into Asset Recognition Criteria (ARC), Disclosure Requirements (DR) and Existing Social Order (ESO). The findings from the study showed that asset recognition criteria and disclosure requirements were highly responsible for the non-accounting 
Abiola, J. O., \& Adisa, R. A. (2020) COVID-19: Influence of Human Resource Accounting Practices on Managerial Decision-Making. Archives of Business Research, 8(5). 8-18.

for Human Resources in Nigeria even on a voluntary basis. Also, existing social order, on the other hand, was statistically significant at $5 \%$ but does not hinder accounting for Human Resources in Nigeria.

Cherian and Farouq (2013) examined the benefits of HRA practices to the firm as well as the theoretical definitions for HRA and challenges faced during implementation of HRA measurement models to predict the organization's performance. The study revealed that since disclosures on human assets act as an evidence for wealth creation, it is resisted by several entrepreneurs.

From the empirical review, it was gathered that previous studies concentrate on various aspects of human resource accounting researches but no work in Nigeria as at the time of writing the paper focuses on human resource accounting practices on managerial decision-making. For instance, Ogenyi and Oladele (2015) studied the challenges to accounting for Human Resources in Nigeria. While Cherian and Farouq (2013) examined the benefits of HRA practices to the firm. In their study, however, Enofe, Mgbame, Otunya and Ovie (2013) examined the relationship between financial performance and human resources accounting disclosures in Nigeria. Isaac, Mayor and James (2017) in another vein studied the influence of human capital accounting information on the market value of listed oil and gas companies in the Nigerian Stock Exchange (NSE).The gap in empirical review therefore necessitates this study.

\section{METHODOLOGY}

The population for the study is the 56firms listed in the financial services sector of the Nigerian Stock Exchange as at the time of the study. Using a random sampling techniques, a sample size of 16 firms was selected due to easy access to information needed. The instrument for data collection was questionnaire designed on a 5 points Likert scale and administered on the personnel ofAccounting, and Audit/Internal Control departments of the sampled firms which were considered to be the relevant departments for this study. 70\% (112) out of the 160 questionnaire distributed to them were returned and analyzed using a simple regression analysis model.

The table below shows the details of the firms examined with the number of questionnaire distributed to them as well as the ones retrieved. 
Table 1: Details of Questionnaires Distributed and Retrieved

\begin{tabular}{|c|c|c|c|}
\hline Firm & $\begin{array}{c}\text { Questionnaire } \\
\text { Distributed }\end{array}$ & $\begin{array}{c}\text { Questionnaire } \\
\text { Retrieved }\end{array}$ & Percent of Return \\
\hline A & 10 & 8 & 7.1 \\
\hline B & 10 & 6 & 5.4 \\
\hline C & 10 & 7 & 6.3 \\
\hline D & 10 & 7 & 6.3 \\
\hline E & 10 & 9 & 8.0 \\
\hline F & 10 & 7 & 6.3 \\
\hline G & 10 & 5 & 4.5 \\
\hline H & 10 & 6 & 5.4 \\
\hline I & 10 & 8 & 7.1 \\
\hline J & 10 & 7 & 6.3 \\
\hline K & 10 & 6 & 5.4 \\
\hline L & 10 & 8 & 7.1 \\
\hline M & 10 & 5 & 4.5 \\
\hline N & 10 & 6 & 5.4 \\
\hline O & 10 & 8 & 7.1 \\
\hline P & 10 & 9 & 8.0 \\
\hline Total & $\mathbf{1 6 0}$ & $\mathbf{1 1 2}$ & $\mathbf{1 0 0 . 0}$ \\
\hline
\end{tabular}

\section{DATA ANALYSIS AND DISCUSSION}

The simple regression model specified for this study is as follows:

$$
\mathrm{Y}=\beta_{\mathrm{o}}+\beta \mathrm{HRAp}+\varepsilon
$$

Where:

$\mathrm{Y}=$ Management Decision

$\beta_{\mathrm{o}}=$ Coefficient (constant) to be estimated

$\beta$ HRAp $=$ Human Resource Accounting Practices

$\varepsilon=$ Stochastic disturbance (error) term

Table 2: Effect of human resources accounting practices on management decision

\begin{tabular}{|c|c|c|c|c|c|c|c|c|}
\hline Model & $\begin{array}{c}\text { Sum of } \\
\text { Squares }\end{array}$ & DF & $\begin{array}{c}\text { Mean Square } \\
\text { (MS) }\end{array}$ & F-Ratio & $\mathbf{R}$ & $\mathbf{R}^{\mathbf{2}}$ & $\begin{array}{c}\text { Adjusted } \\
\mathbf{R}^{\mathbf{2}}\end{array}$ & Sig. \\
\hline Regression & 13.681 & 1 & 13.681 & 121.759 & $.714^{\mathrm{a}}$ & .508 & .504 & $.000^{\mathrm{b}}$ \\
\hline Residual & 13.259 & 118 & .112 & & & & & \\
\hline Total & 26.940 & 119 & & & & & & \\
\hline
\end{tabular}

a. Dependent Variable: Management Decision

b. Predictors: (Constant), Human Resource Accounting

Source: Researcher's field survey result from SPSS (2018)

Table 2 above shows that human resource accounting practices significantly affect managerial decisions as indicated by the $\mathrm{p}=0.000$, with $\mathrm{R}^{2}$ value and the adjusted $\mathrm{R}^{2}$ at 0.508 and 0.504 respectively. 
Abiola, J. O., \& Adisa, R. A. (2020) COVID-19: Influence of Human Resource Accounting Practices on Managerial Decision-Making. Archives of Business Research, 8(5). 8-18.

The $\mathrm{R}^{2}$ value of 0.508 represents the rate of changes in management decision that is accounted for by organizations' human resource accounting practices. Thus the result shows that human resources contribute at least $50.8 \%$ to management decisions.

Table 3: Parameters of Estimates of the Relative Contribution Identified Variable (Human Resource Accounting Practices) To the Management Decision.

\begin{tabular}{|c|c|c|c|c|c|c|}
\hline \multicolumn{2}{|c|}{ Model } & \multicolumn{2}{c|}{$\begin{array}{c}\text { Unstandardized } \\
\text { Coefficients }\end{array}$} & $\begin{array}{c}\text { Standardized } \\
\text { Coefficients }\end{array}$ & \multirow{2}{*}{ t } & \multirow{2}{*}{ Sig. } \\
\cline { 2 - 7 } \multicolumn{2}{|c|}{} & B & Std. Error & Beta & & \\
\hline \multirow{3}{*}{1} & (Constant) & 1.067 & .299 & & 3.566 & .001 \\
\cline { 2 - 7 } & $\begin{array}{c}\text { Human Resource } \\
\text { Accounting Practices }\end{array}$ & .772 & .070 & .713 & 11.034 & .000 \\
\hline \multicolumn{7}{|c|}{ a. Dependent Variable: Management Decision } \\
\hline
\end{tabular}

Source: Researcher's field survey result from SPSS (2018)

Furthermore, table 3 shows that the $\beta$ value of human resource which is the independent variable in the regression model stated above is 0.772 , with $\mathrm{p} \leq 0.000$. This isan indication that human resource accounting practice has a significant contribution to management decisions.

This result agrees with Enyi and Adebawojo (2014) who found a significant effect of human asset accounting on management decision. It is also in tandem with Islam, Kamruzzaman and Redwanuzzaman (2013) who in their study on the recognition and disclosure of accounting methods and techniques in relation to human resource accounting found that HRA develops effective managerial decision making. This implies that human resource in organization could either make or mar the organization in terms of decision making because it does not matter how much physical asset an organization has without human asset to drive it and make good decisions.

The above findings agree with the findings of Okpala and Chidi (2010) who established from their study that a well-developed system of human resource capital accounting could contribute significantly to internal decisions by management and external decisions by investors. Also the study of Fariborz and Raiasheka (2011) on Iranian companies supported the above findings. The results of their findings revealed that human resources accounting (HRA) information can play a critical role in internal managerial decision making and its measures can be used to show that that investment in company's human resources may result in long term profit for the company.

This study therefore achieves its objective which is to examine the influence of Human Resource Accounting on managerial decision-making through the results derived after the analysis of gathered data. The study also found that HRA is significant in the context of management planning on human resources.

\section{CONCLUSIONS AND RECOMMENDATIONS}

Consequent upon the findings from this study which showed that human resource significantly affect managerial decision-making as supported by prior empirical studies and relevant literature such as Enyi and Adebawojo (2014), Islam, Kamruzzaman and Redwanuzzaman (2013), Fariborz and Raiasheka (2011), Okpala and Chidi (2010), there is need for human asset to be given adequate recognition like goodwill in the statement of financial positions of organizations as they (human resource) are key to the survival and going concern yearned for by the organizations. However, 
HRA disclosure should be stated in the organization's statement of financial position (Balance Sheet) and not as a mere expense debited to statement of comprehensive income (Profit and Loss Account).

In view of the foregoing, it is therefore recommended that the local financial regulatory body like the Financial Reporting Council of Nigeria (FRCN) should make timely pronouncement as regard the recognition of HRA cost in organizations' statement of financial position and the International Accounting Standard Board (IASB) should provide relevant International Financial Reporting Standard (IFRS) aimed at the recognition of human resource cost in organization's financial position and not to be treated as a mere expense in the organizations' statement of comprehensive income in order to enhance adequate decision-making in business organizations premised on fair financial reporting.

\section{References}

American Accounting Association (1973). Report of the committee on human resource accounting. The Accounting Review, 48, 169-185. Retrieved on February 4, 2018from http://www.jstor.org/

Anita, S. \& Nader, N. (2014). Impact of human resource accounting on managers' decision making in organizations. International Research Journal of Management and Commerce, 1(4), 14-25.

Arkan, T. (2016). Human Resources Accounting: A Suggested Model for Measurement and Valuation. Finanse, Rynki Finansowe, Ubezpieczenia, 1 (79), 173-193. Available at www.wneiz.pl/frfu.

Badmus, S. O. \& Abata, M. A. (2010). Human capital and financial reporting: A case of Nigeria. Nigerian Journal of Management Studies, 10(2), 23-45.

Bassey, E. B. \& Arzizeh, T. T. (2012). Capitalized human resources cost and its influence on corporate productivity: A study of selected companies in Nigeria. International Journal of Financial Research, 3(2), 48-59.

Bhumika, B. (2016). Comparative study of human resource accounting in Infosys Technology Limited. International Journal of Development Research, 6(12), 10868-10872.

Cherian, J. \& Farouq, S. (2013). A Review of Human Resource Accounting and Organizational Performance. International Journal of Economics and Finance, 5(8), 74-83.

Enofe, A. O., Mgbame, C., Otunya, S. \& Ovie, C. (2013). Human resources accounting disclosure in Nigeria quoted firms. Research Journal of Finance and Accounting, 4(13), 7-12.

Enyi, P. E \& Adebawojo, O. A. (2014). Human Resource Accounting and decision making in post-industrial economy. American International Journal of Contemporary Research, 4(2), 110-118

Ezejiofor, R. A., John-Akamelu, R. C. \& Iyidiobi, F. C. (2017). Appraisal of Human Resource Accounting on Profitability of Corporate Organization. Economics, 6(1), 1-10.

Fariborz A., \& Raiashekar, H. (2011). Decision-making based on human resource accounting information and itsevaluation method. Asian Journal of Finance and Accounting, 3(1), 1-14.

Fariborz, A. \& Rajashekar, H. (2011). Decision-Making Based on Human Resource Accounting Information and Its Evaluation Method. Asian Journal of Finance and Accounting, 3(1), 1-13.

Isaac, O. I., Mayor, B. M. \& James, O. (2017). Human capital accounting and market value of oil and gas companies in Nigeria. International Journal of Innovative Research in Science, Engineering and Technology, 6(11), 21364-21369.

Islam, A., Kamruzzaman \& Redwanuzzaman (2013). Human Resource Accounting: Recognition and disclosure of accounting methods and techniques. Global Journal of Management and Business Research, 13(3), 1-10.

Micah, L. C., Ofurum, C. O. \& Ihendinihu, J. U. (2012). Firms' financial performance and Human Resource Accounting Disclosure in Nigeria. International Journal of Business and Management, 7(14), 67-75. 
Abiola, J. O., \& Adisa, R. A. (2020) COVID-19: Influence of Human Resource Accounting Practices on Managerial Decision-Making. Archives of Business Research, 8(5). 8-18.

Ogenyi, M. A.\& Oladele, K. O. (2015). Human Resource Accounting (HRA) in Nigeria: an analysis of challenges.

Research Journal of Finance and Accounting, 6(22), 15-20.

Okpala, P.O.\& Chidi, O.C. (2010). Human Capital Accounting and its Relevance to Stock Investment Decisions in Nigeria, European Journal of Economics, Finance and Administrative Sciences, Issue 22, 65-76.

\section{APPENDICES APPENDIX A}

Questionnaire cover letter

A survey on the influence of human resource accounting practices on managerial decisionmaking

Dear respondents,

We are currently conducting a research on the topic: Influence of Human Resource Accounting (HRA) practices on Managerial Decision-Making.

We hereby solicit for your opinion through the medium of questionnaire.

This questionnaire is purely for academic research purpose. Any information provided will be strictly treated confidentially and will be used for the purpose which it was meant for. As such your identity is not required.

Thank you so much in anticipation of your cooperation and assistance.

Yours Sincerely,

Researchers

\section{Questionnaire}

\section{Dear Respondents,}

Please express your opinion on a five-point scale on the following statements on the "Influence of Human Resource Accounting (HRA) information on Managerial Decision-making".

The working definition for this study is as follows: Human Resource Accounting is the process of measuring the cost and value of human resources to an organization and presenting the information in a significant manner in the financial statements to communicate their value to the different stakeholders. It mainly caters to the information need of the HR professionals, senior managers and investors for making effective decisions.

Your cooperation is earnestly solicited for carrying out an effective research.

\section{Section A}

1. Does your organization have a Human Resource Accounting (HRA) system in operation?

$$
\text { Yes }
$$

No

2. If your answer to above question is yes, please specify the HRA model you are following.

3. If your answer to Question 1 is no, please mention the reasons for not introducing HRA on a five point scale of $\mathbf{1}$ (not at all relevant) to $\mathbf{5}$ (fully relevant):

\begin{tabular}{|c|c|c|c|c|c|c|}
\hline SN & ITEM & 1 & 2 & 3 & 4 & 5 \\
\hline 1 & $\begin{array}{l}\text { The challenge of designing HRA systems which are capable of providing } \\
\text { accurate and reliable information about human resources. }\end{array}$ & & & & & \\
\hline 2 & Disclosure of HR information is not mandatory & & & & & \\
\hline 3 & Lack of standards & & & & & \\
\hline 4 & $\begin{array}{l}\text { The notion that putting a price on people may make human beings } \\
\text { substitutable to other forms of capital [Ethical issue] }\end{array}$ & & & & & \\
\hline
\end{tabular}


Archives of Business Research (ABR)

Vol.8, Issue 5, May-2020

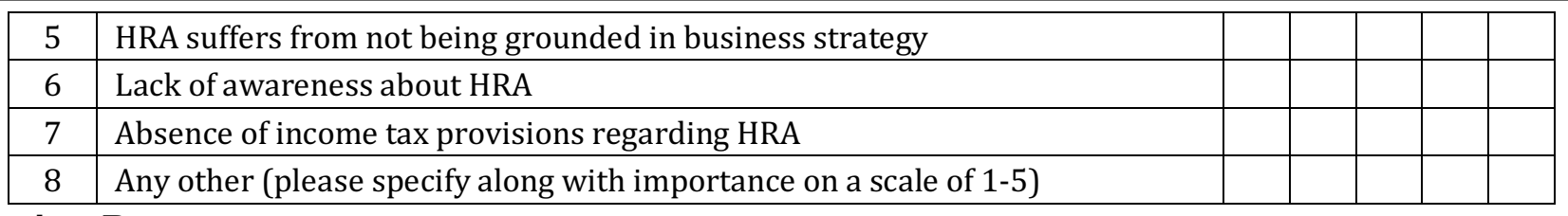

\section{Section B}

Kindly tick the appropriate box and please take note that:

\begin{tabular}{|c|c|c|c|c|c|c|}
\hline SN & Items & SA & $\mathbf{A}$ & $\mathbf{N}$ & $\mathbf{D}$ & SD \\
\hline 1 & $\begin{array}{l}\text { HRA serves as a framework to facilitate human resource decision- } \\
\text { making. }\end{array}$ & & & & & \\
\hline 2 & $\begin{array}{l}\text { HRA provides numerical information about the cost and value of people } \\
\text { as organizational resources. }\end{array}$ & & & & & \\
\hline 3 & $\begin{array}{l}\text { HRA provides a perspective for analyzing the effects of decisions on the } \\
\text { human organization and for explaining the consequences to } \\
\text { management. }\end{array}$ & & & & & \\
\hline 4 & $\begin{array}{l}\text { HRA system helps to attract investors through proper disclosure of } \\
\text { information about the human resources of an organization in the } \\
\text { annual reports. }\end{array}$ & & & & & \\
\hline 5 & $\begin{array}{l}\text { HRA facilitates the various aspects of human resource planning by } \\
\text { providing information to management on historical costs of recruiting, } \\
\text { hiring, and training and so on. }\end{array}$ & & & & & \\
\hline 6 & $\begin{array}{l}\text { HRA plays a vital role in personnel selection as it can provide } \\
\text { information about the future value to the organization of the different } \\
\text { job candidates. }\end{array}$ & & & & & \\
\hline 7 & $\begin{array}{l}\text { HRA facilitates decisions involving the allocation of resources to human } \\
\text { resource development by measuring the expected rate of return on } \\
\text { proposed investments. }\end{array}$ & & & & & \\
\hline 8 & $\begin{array}{l}\text { HRA is useful to management in formulating policy for human resource } \\
\text { acquisition and development. }\end{array}$ & & & & & \\
\hline 9 & $\begin{array}{l}\text { HRA is useful to management in making decisions regarding the } \\
\text { allocation/placement of human resources to various jobs. }\end{array}$ & & & & & \\
\hline 10 & $\begin{array}{l}\text { HRA provides a framework to help managers utilize human resources } \\
\text { effectively and efficiently. }\end{array}$ & & & & & \\
\hline 11 & $\begin{array}{l}\text { HRA provides vital information to know whether the human resources } \\
\text { have been properly utilized. }\end{array}$ & & & & & \\
\hline 12 & $\begin{array}{l}\text { HRA has an impact on the administration of reward systems. It enables } \\
\text { management to base compensation decisions on the value of people to } \\
\text { the firm. }\end{array}$ & & & & & \\
\hline 13 & $\begin{array}{l}\text { HRA provides vital information for career planning and development of } \\
\text { the employee. }\end{array}$ & & & & & \\
\hline 14 & $\begin{array}{l}\text { HRA is used to evaluate the efficiency of HR departments. It provides } \\
\text { certain standards costs with respect to acquisition, development, etc. of } \\
\text { people, and these standards can be compared with the actual costs } \\
\text { incurred by the department. }\end{array}$ & & & & & \\
\hline 15 & $\begin{array}{l}\text { HRA provides feedback to the managers on their performance in } \\
\text { managing human resources. }\end{array}$ & & & & & \\
\hline 16 & $\begin{array}{l}\text { HRA helps to take decisions with respect to allocation of funds for } \\
\text { employee welfare amenities. }\end{array}$ & & & & & \\
\hline 17 & HRA information has utility in making personnel layoff decisions. & & & & & \\
\hline 18 & It is possible to use HRA in budgeting training and development costs. & & & & & \\
\hline
\end{tabular}


Abiola, J. O., \& Adisa, R. A. (2020) COVID-19: Influence of Human Resource Accounting Practices on Managerial Decision-Making. Archives of Business Research, 8(5). 8-18.

\begin{tabular}{|c|l|c|c|c|c|}
\hline \hline $\mathbf{1 9}$ & $\begin{array}{l}\text { HRA offers vital monetary argument for solving employer-employee } \\
\text { disputes. }\end{array}$ & & & & \\
\hline $\mathbf{2 0}$ & $\begin{array}{l}\text { HRA helps to take decisions with respect to investments to be made in } \\
\text { research and development. }\end{array}$ & & & \\
\hline
\end{tabular}

SA = 'Strongly Agree'. A = 'Agree'. N = 'Neutral'. D = 'Disagree'. SD = 'Strongly Disagree'

\section{Data Analysis}

\section{APPENDIX B}

\section{Regression Analysis Result}

\begin{tabular}{|c|c|c|c|}
\hline \multicolumn{4}{|c|}{ Variables Entered/Removeda } \\
\hline Model & Variables Entered & Variables Removed & Method \\
\hline 1 & $\begin{array}{c}\text { Human Resource } \\
\text { Accountingb }\end{array}$ & $\cdot$ & Enter \\
\hline \multicolumn{4}{|c|}{ a. Dependent Variable: Management Decision } \\
\hline \multicolumn{4}{|c|}{ b. All requested variables entered. } \\
\hline
\end{tabular}

\begin{tabular}{|c|c|c|c|c|}
\hline \multicolumn{5}{|c|}{ Model Summary } \\
\hline \multirow{2}{*}{ Model } & $\mathrm{R}$ & R Square & $\begin{array}{c}\text { Adjusted R } \\
\text { Square }\end{array}$ & $\begin{array}{c}\text { Std. Error of } \\
\text { the Estimate }\end{array}$ \\
\hline 1 & $.713^{\mathrm{a}}$ & .508 & .504 & .3352055 \\
\hline
\end{tabular}

a. Predictors: (Constant), Human Resource Accounting

\begin{tabular}{|c|c|c|c|c|c|c|}
\hline \multicolumn{7}{|c|}{ ANOVA $^{\mathbf{a}}$} \\
\hline \multirow{3}{*}{1} & Model & Sum of Squares & df & Mean Square & F & Sig. \\
\cline { 2 - 8 } & Regression & 13.681 & 1 & 13.681 & 121.759 & $.000^{\mathrm{b}}$ \\
\cline { 2 - 7 } & Residual & 13.259 & 118 & .112 & & \\
\cline { 2 - 7 } & Total & 26.940 & 119 & & & \\
\hline \multicolumn{7}{|c|}{ a. Dependent Variable: Management Decision } \\
\hline
\end{tabular}

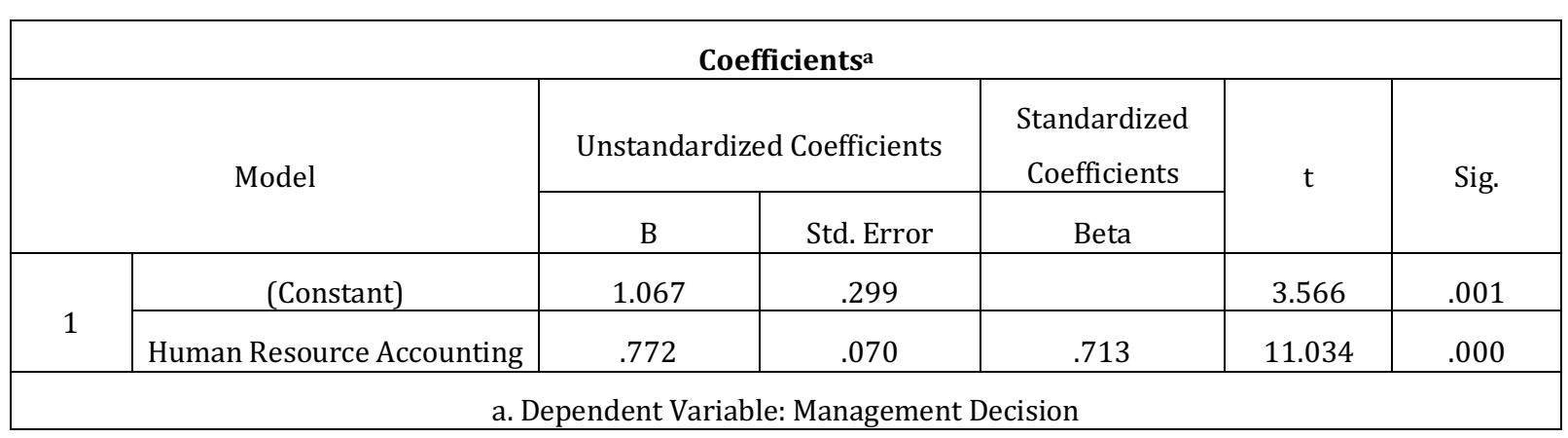

\section{Source: SPSS Output}

